\title{
Social Impact Assessment on PT Adaro Indonesia's CSR Program
}

\author{
Aan Nurhadi ${ }^{1}$, Arief Soendjoto ${ }^{2}$, Rudi Fakhriadi ${ }^{2}$, Nita Pujianti ${ }^{2}$, Lenie Marlinae ${ }^{2}$, M. Syarif \\ Hidayatullah $^{2}$, Lalily Khairiyati ${ }^{2}$, Agung Waskito ${ }^{2}$, Noor Ahda Fadillah ${ }^{2}$, Nida Ulfah ${ }^{2}$ \\ ${ }^{1}$ Corporate Social Responsibility PT Adaro Indonesia, Balangan, \\ ${ }^{2}$ Faculty of Medicine, University of Lambung Mangkurat \\ DOI: 10.29322/IJSRP.11.08.2021.p11646 \\ http://dx.doi.org/10.29322/IJSRP.11.08.2021.p11646
}

\begin{abstract}
Ambahai Village is one of the Company's operational villages located in Paminggir District, Hulu Sungai Utara Regency (HSU)..Ambahai village is the first village that has implemented the Integrated Posyandu program in 2010 from the CSR program of PT. Adaro Indonesia. The purpose of conducting a social impact study on the integrated posyandu program is to identify the important impacts of the implementation of community empowerment programs that have the potential to be a source of impact on the social environment of the community. Significant impacts that arise can be in the form of positive or negative impacts, either directly or indirectly. The research subjects were the people in 7 villages in Paminggir sub-district, namely Sapala, Bararawa, Tampakang, Paminggir, Paminggir Seberang and Pal Batu villages. This type of research is qualitative and quantitative research. The instruments used were a structured interview technical guide, an in-depth interview technical guide, a field observation technical guide, a FGD technical guide, data entry formats as needed in the social impact assessment process according to field conditions. Based on the results of the study, it is known that based on economic, health, socio-cultural variables, there are various positive and negative impacts on each program implemented. 5. Calculation of Social Return of Investment (SROI) for integrated posyandu program in Ambahai village $27.01: 1$, for Paminggir village $12.93: 1$, Paminggir Seberang village $17.73: 1$, Palbatu village 32.25 $: 1$, Tampakang village $33,60: 1$, Sapala village $39.44: 1$, Bararawa village $37.01: 1$. The programs are cooperatives, skill improvement programs, PAUD, Posyandu for toddlers, pregnant women, the elderly, Maulid Habsyi, waste management, clean water treatment, and disposal of feces and waste water.
\end{abstract}

Keywords :.Integral Posyandu, SROI, Adaro Indonesia

\section{INTRODUCTION}

A mbahai Village is one of the Company's operational villages located in Paminggir District, Hulu Sungai Utara Regency (HSU). Villages in Paminggir
Subdistrict, including Ambahai Village, are classified as villages with a high level of difficulty and remote villages in accordance with HSU Regent Regulation Number: 32 of 2011, considering the distance between the village and the Regency Capital is about $60 \mathrm{~km}$ which can be reached by land and water. For the waterway, it takes about 1 hour if you use fast water facilities (speed boat). This also happened with 6 other villages in Paminggir Subdistrict, Hulu Sungai Utara Regency.

The total population in Ambahai is 297 households/1037 people (male and female) spread over 6 neighborhood units (RT) (Source: 2018 village data), with the character of the area in the form of tidal swamps, so that the daily lives of many people spent in the swampy waters and the majority of the community work as freshwater fish fishermen and raise swamp buffalo.

Ambahai village is the first village that has implemented the Integrated Posyandu program in 2010 from the CSR program of PT. Adaro Indonesia. The implementation of Integrated Posyandu is motivated by the lack of access to education and health for the community in Ambahai Village and other villages in Paminggir District.

Integrated Posyandu activities focus on health activities (posyandu for mothers, children, the elderly) and early childhood education (PAUD) for toddlers. Until 2018, the implementation of integrated posyandu has been in 7 villages throughout the Paminggir sub-district and in several other districts such as in Balangan, Tabalong and South Barito.

Figure 1.1 Beneficiaries of the Integrated Posyandu Program in Ambahai Village 


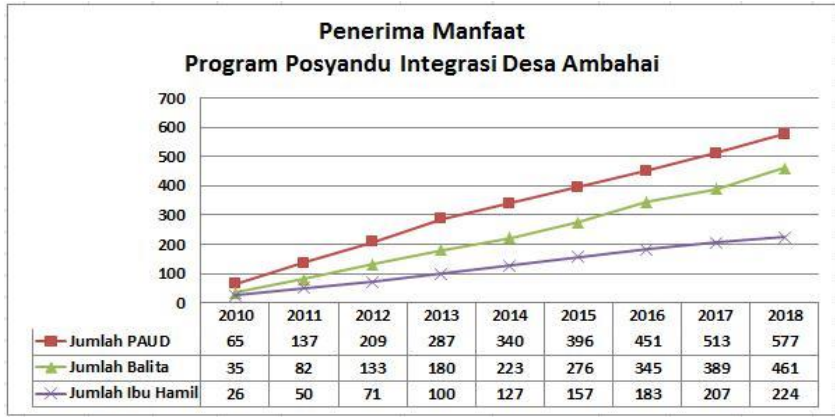

This has also happened in other villages that have implemented Integrated Posyandu, namely in Sapala, Bararawa, Tampakang, Paminggir, Paminggir Seberang and Pal Batu villages. Duplicate implementation of integrated posyandu in accordance with the Company's CSR plan with the community in Paminggir District, where every year one unit is built in the village based on the level of assessment according to the following parameters:

Table 1 Categories of Integrated Posyandu Assessment

\begin{tabular}{|c|c|c|c|c|c|c|c|c|c|c|}
\hline \multirow{2}{*}{ Village Name } & \multicolumn{2}{|c|}{ Weight } & \multicolumn{6}{|c|}{ Rating Category } & \multirow{2}{*}{ Total } & \multirow{2}{*}{ Rank } \\
\hline & Scale & Mark & HR & Land & $\begin{array}{c}\text { Aspiratio } \\
n\end{array}$ & Institutional & Material & Enthusiasm & & \\
\hline Paminggir & 1 & $\begin{array}{c}\text { Not } \\
\text { available }\end{array}$ & 3 & 3 & 3 & 4 & 3 & 4 & 20 & 2 \\
\hline $\begin{array}{l}\text { Paminggir } \\
\text { Seberang }\end{array}$ & 2 & $\begin{array}{c}\text { Less } \\
\text { available }\end{array}$ & 3 & 2 & 2 & 3 & 1 & 2 & 13 & 4 \\
\hline Ambahai & 3 & $\begin{array}{l}\text { Sufficientl } \\
\text { y available }\end{array}$ & 4 & 4 & 4 & 4 & 3 & 4 & 23 & 1 \\
\hline Palbatu & 4 & Adequate & 4 & 3 & 3 & 3 & 2 & 3 & 18 & 3 \\
\hline Tampakang & 5 & $\begin{array}{c}\text { Very } \\
\text { available }\end{array}$ & 2 & 2 & 2 & 2 & 3 & 1 & 12 & 5 \\
\hline Sapala & & & 3 & 2 & 2 & 1 & 2 & 1 & 11 & 6 \\
\hline Bararawa & & & 3 & 1 & 2 & 1 & 1 & 1 & 9 & 7 \\
\hline
\end{tabular}

However, since the implementation of this integrated posyandu, there has never been a study of the impact and social investment (Social Return on Investment) that occurred during the integration of posyandu in villages in Paminggir sub-district. In fact, this study is very much needed to provide information and justify the impact of the program on community development activities in Paminggir District which are carried out by PT Adaro Indonesia.

The purpose of conducting a social impact study on the integrated posyandu program is to identify the important impacts of the implementation of community empowerment programs that have the potential to be a source of impact on the social environment of the community. Significant impacts that arise can be in the form of positive or negative impacts, either directly or indirectly. Identify the social environment, especially those that will be affected when development is carried out. The components of the social environment that will be identified include demographics, socio-economics, and community culture. Describe and measure the significant impact of potential activities on the socio-economic and socio-cultural environment of the community, both positive and negative. As justification that the community empowerment program carried out by the company has a positive social impact from the economic, environmental, social and cultural perspective. Analyzing the possibility of preventing and or controlling unwanted impacts and increasing the desired impacts so that the community can benefit from the changes that occur. Monitor the implementation of development and mitigation strategies. Calculating and analyzing social return on investment (SROI) for integrated posyandu programs for companies and the community. Monitor the implementation of development and mitigation strategies. Calculating and analyzing social return on investment (SROI) for integrated posyandu programs for companies and the community. Monitor the implementation of development and mitigation strategies. Calculating and analyzing social return on investment (SROI) for integrated posyandu programs for companies and the community.

\section{RESEARCH METHOD}

The research subjects were the people in 7 villages in Paminggir sub-district, namely Sapala, Bararawa, 
Tampakang, Paminggir, Paminggir Seberang and Pal Batu villages. This type of research is qualitative and quantitative research. Informants in this study are beneficiaries of the Integrated Posyandu program. This includes village officials, integrated posyandu program actors (PAUD teachers, Posyandu cadres, village cadres and posyandu beneficiaries such as pregnant women, mothers of toddlers to the elderly). The data collection process used field observation, in-depth interviews and focus group discussions (FGD). The instruments used are structured interview technical guide, in-depth interview technical guide, field observation technical guide, FGD technical guide, data entry format as needed in the social impact assessment process according to field conditions. Data processing and analysis techniques use coding, data classification, analyzing meaning units in categories, Table 2 Scope creation and identification of Ambahai Village stakeholders

\begin{tabular}{|c|c|c|c|}
\hline Scope / Stage & Stakeholders & Amount & Form of Role / Linkage \\
\hline \multicolumn{4}{|l|}{ Benefit recipients : } \\
\hline \multicolumn{4}{|l|}{ Health program } \\
\hline Mother's Posyandu & Pregnant mother & 10 People & $\begin{array}{l}\text { Pregnancy check-up (ANC) } \\
\text { Giving blood-added tablets } \\
\text { Pregnancy counseling } \\
\text { Giving birth control } \\
\text { drugs }\end{array}$ \\
\hline Children's Posyandu & Toddler & 72 People & $\begin{array}{l}\text { Giving worm medicine } \\
\text { Giving vitamins } \\
\text { Supplementary Feeding } \\
\text { Immunization } \\
\text { Weighing } \\
\text { Child nutrition education }\end{array}$ \\
\hline Elderly Posyandu & seniors & 30 People & $\begin{array}{l}\text { Drug administration } \\
\text { Medical examination } \\
\text { Health education }\end{array}$ \\
\hline \multicolumn{4}{|l|}{ Socio-cultural program } \\
\hline PAUD & Toddler & 58 people & $\begin{array}{l}\text { early childhood education } \\
\text { programs }\end{array}$ \\
\hline Maulid Group & Manager & 1 group & habsyi birthday service \\
\hline \multicolumn{4}{|c|}{ Economic program Program } \\
\hline Cooperative & Manager & 3 people & $\begin{array}{l}\text { Stationery Sales } \\
\text { Photocopy service } \\
\text { Laminate services } \\
\text { savings and Loan } \\
\text { Sales of cakes and food } \\
\text { light }\end{array}$ \\
\hline \multicolumn{4}{|l|}{ Environmental Program } \\
\hline Garbage bank & Manager & & Waste bank management \\
\hline \multicolumn{4}{|l|}{ Manager: } \\
\hline Planning and Principles & $\begin{array}{l}\text { 1. Company } \\
\text { 2. Village Apparatus }\end{array}$ & & $\begin{array}{l}\text { Building funding } \\
\text { Facility }\end{array}$ \\
\hline Implementation & $\begin{array}{l}\text { 1. Medical personnel } \\
\text { Health Center and Village }\end{array}$ & & 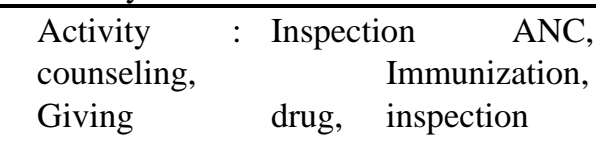 \\
\hline
\end{tabular}

This publication is licensed under Creative Commons Attribution CC BY. http://dx.doi.org/10.29322/IJSRP.11.08.2021.p11646 looking for relationships between categories, and making reports.

\section{FINDINGS}

The integrated posyandu program in Ambahai village consists of activities for health posyandu (elderly, toddlers and pregnant women), Early Childhood Education (PAUD), Cooperatives, Maulid Habsyi Group and Waste Bank. Based on the results of interviews with stakeholders, namely village heads, posyandu cadres, elderly posyandu participants, toddlers, and pregnant women, early childhood teachers, early childhood parents, cooperative management, cooperative consumers, Maulid habsyi management and waste bank managers. Based on these 5 (five) activities, the impact on health, environment, economy and socio-culture was obtained. 


$$
\text { 2. Posyandu cadres }
$$

elderly health

Activity : counseling, Giving PMT, weighing

Activity : learning child early age
The integrated posyandu program in Paminggir village consists of Health Posyandu (elderly, toddlers and pregnant women) and Early Childhood Education (PAUD). However, because in Paminggir village there is also an independent PAUD which is closer to people's homes, parents prefer independent PAUD compared to PAUD formed by integrated posyandu and integrated PAUD posyandu in Paminggir village does not work because there are no students. Based on the results of interviews with village heads, posyandu cadres, the elderly, mothers of toddlers, pregnant women, and early childhood teachers, it was found that the health and environmental impact

\begin{tabular}{|c|c|c|c|}
\hline Scope / Stage & Stakeholders & Amount & Form of Role / Linkage \\
\hline \multicolumn{4}{|l|}{ Benefit recipients : } \\
\hline Mother's Posyandu & Pregnant mother & 12 people & $\begin{array}{l}\text { Pregnancy test } \\
\text { (ANC) } \\
\text { Giving additional tablets } \\
\text { blood } \\
\text { Pregnancy counseling } \\
\text { Giving birth control drugs }\end{array}$ \\
\hline Children's Posyandu & Toddler & 60 People & $\begin{array}{l}\text { Giving worm medicine } \\
\text { Giving vitamins } \\
\text { Feeding } \\
\text { Addition } \\
\text { Immunization } \\
\text { Weighing } \\
\text { Child nutrition education }\end{array}$ \\
\hline Elderly Posyandu & seniors & 40 people & $\begin{array}{l}\text { Drug administration } \\
\text { Medical examination } \\
\text { Health education }\end{array}$ \\
\hline \multicolumn{4}{|l|}{ Manager: } \\
\hline $\begin{array}{l}\text { Planning and } \\
\text { Principle }\end{array}$ & $\begin{array}{l}\text { 1. Company } \\
\text { 2. Village Apparatus }\end{array}$ & & $\begin{array}{l}\text { Building funding } \\
\text { Facility }\end{array}$ \\
\hline Implementation & $\begin{array}{l}\text { 3. Health center medical personnel } \\
\text { 4. Posyandu Cadres }\end{array}$ & & $\begin{array}{ll}\text { Activity } & \text { Inspection } \\
\text { ANC, } & \text { counseling, } \\
\text { Immunization, } & \text { Giving } \\
\text { drug, } & \text { inspection } \\
\text { elderly health } & \\
\text { Activity } & \text { : counseling, } \\
\text { Giving } & \text { PMT, } \\
\text { weighing } & \end{array}$ \\
\hline
\end{tabular}

Table 3 Scope Making and Identification of Stakeholders in Paminggir Village

The integrated posyandu program in Paminggir opposite village consists of 2 (two) activities, namely the health posyandu program (elderly, toddlers, pregnant women) and early childhood education (paud). Based on the results of interviews with stakeholders, it is known that the impact of the integrated posyandu program consists of health, environmental and socio-cultural impacts

Table 4 Scope Making and Identification of Stakeholders in Paminggir Seberang Village

\begin{tabular}{|l|l|l|l|}
\hline Scope / Stage & Stakeholders & & Form of Role / Linkage \\
\hline Benefit recipients : & & Amount & \\
\hline Mother's Posyandu & Pregnant mother & 5 people & Pregnancy test
\end{tabular}

This publication is licensed under Creative Commons Attribution CC BY. 


\begin{tabular}{|c|c|c|c|}
\hline & & & $\begin{array}{l}\text { (ANC) } \\
\text { Giving additional tablets } \\
\text { blood } \\
\text { Pregnancy counseling } \\
\text { Giving birth control drugs }\end{array}$ \\
\hline Children's Posyandu & Toddler & 74 people & $\begin{array}{l}\text { Giving worm medicine } \\
\text { Giving vitamins } \\
\text { Feeding } \\
\text { Addition } \\
\text { Immunization } \\
\text { Weighing } \\
\text { Child nutrition education }\end{array}$ \\
\hline Elderly Posyandu & seniors & 60 People & $\begin{array}{l}\text { Drug administration } \\
\text { Medical examination } \\
\text { Health education }\end{array}$ \\
\hline PAUD & Toddler & 12 people & $\begin{array}{ll}\text { early childhood education } \\
\text { programs }\end{array}$ \\
\hline Manager: & & & \\
\hline $\begin{array}{l}\text { Planning and } \\
\text { Principle }\end{array}$ & $\begin{array}{l}\text { 3. Company } \\
\text { 4. Village Apparatus }\end{array}$ & & $\begin{array}{l}\text { Building funding } \\
\text { Facility }\end{array}$ \\
\hline Implementation & $\begin{array}{l}\text { 6. Health center medical personnel } \\
\text { 7. Posyandu cadres } \\
\text { 8. PAUD teacher }\end{array}$ & & 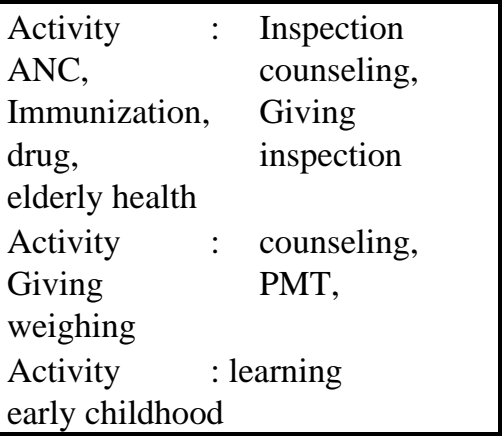 \\
\hline
\end{tabular}

The integrated posyandu program in Bararawa village consists of health posyandu (elderly, pregnant women, toddlers). Meanwhile, the PAUD program has not yet been opened because in the village of Bararawa near the
Posyandu, there are already independent PAUDs with villages. The impacts obtained from health posyandu activities are health impacts and environmental impacts.

Table 5 Scope Making and Identification of Stakeholders in Bararawa Village

\begin{tabular}{|l|l|l|l|}
\hline Scope / Stage & Stakeholders & Amount & Form of Role / Linkage \\
\hline Benefit recipients : & & & \\
\hline Mother's Posyandu & Pregnant mother & 15 People & $\begin{array}{l}\text { Pregnancy check-up (ANC) } \\
\text { Giving of blood-added tablets } \\
\text { Pregnancy counseling } \\
\text { Giving birth control drugs }\end{array}$ \\
\hline Children's Posyandu & Toddler & 65 People & $\begin{array}{l}\text { Giving worm medicine } \\
\text { Giving vitamins } \\
\text { Supplementary Feeding } \\
\text { Immunization } \\
\text { Weighing } \\
\text { Child nutrition education }\end{array}$ \\
\hline Elderly Posyandu & & 85 People & $\begin{array}{l}\text { Drug administration } \\
\text { Medical examination }\end{array}$ \\
\hline
\end{tabular}




\begin{tabular}{|l|l|l|} 
& & Health education \\
\hline Manager: & & \\
\hline Planning and Principles & $\begin{array}{l}\text { Company } \\
\text { Village Apparatus }\end{array}$ & $\begin{array}{l}\text { Building funding } \\
\text { Facility }\end{array}$ \\
\hline Implementation & Health center medical personnel & $\begin{array}{l}\text { Activities: ANC examination, } \\
\text { Counseling, Immunization, Giving } \\
\text { medicine, health check } \\
\text { elderly } \\
\end{array}$ \\
& & $\begin{array}{l}\text { Activities: Counseling, Giving } \\
\text { PMT, weighing }\end{array}$ \\
\hline
\end{tabular}

The integrated posyandu program in Palbatu village consists of two activities, namely health posyandu (elderly, toddlers, pregnant women) and PAUD. The impacts resulting from these 2 (two) activities are health, environmental and socio-cultural impacts

Table 5.21 Scope Making and Identification of Stakeholders in Palbatu Village

\begin{tabular}{|c|c|c|c|}
\hline Scope / Stage & Stakeholders & & Form of Role / Linkage \\
\hline Benefit recipients : & & Amount & \\
\hline Mother's Posyandu & Pregnant mother & 7 people & $\begin{array}{l}\text { Pregnancy test } \\
\text { (ANC) } \\
\text { Giving additional tablets } \\
\text { blood } \\
\text { Pregnancy counseling } \\
\text { Giving birth control drugs }\end{array}$ \\
\hline Children's Posyandu & Toddler & 53 People & $\begin{array}{l}\text { Giving worm medicine } \\
\text { Giving vitamins } \\
\text { Feeding } \\
\text { Addition } \\
\text { Immunization } \\
\text { Weighing } \\
\text { Child nutrition education }\end{array}$ \\
\hline Elderly Posyandu & seniors & 19 People & $\begin{array}{l}\text { Drug administration } \\
\text { Medical examination } \\
\text { Health education }\end{array}$ \\
\hline PAUD & Toddler & 53 people & $\begin{array}{ll}\text { early childhood education } \\
\text { programs }\end{array}$ \\
\hline \multicolumn{4}{|l|}{ Manager: } \\
\hline Planning and Principles & $\begin{array}{l}\text { Company } \\
\text { Village Apparatus }\end{array}$ & & $\begin{array}{l}\text { Building funding } \\
\text { Facility }\end{array}$ \\
\hline Implementation & $\begin{array}{l}\text { Medical personnel } \\
\text { Public health center } \\
\text { Posyandu cadres } \\
\text { PAUD teacher }\end{array}$ & & $\begin{array}{lll}\text { Activity } & : & \begin{array}{l}\text { Inspection } \\
\text { counseling, }\end{array} \\
\text { ANC, } & \text { counsization, } & \text { Giving } \\
\text { Immunize } & \text { inspection } \\
\text { drug, elderly health } & \\
\text { Activity }: & \text { counseling, } \\
\text { Giving } & \text { PMT, } \\
\text { weighing } & \\
\text { Activity : learning } \\
\text { early childhood }\end{array}$ \\
\hline
\end{tabular}

The integrated posyandu program in Sapala village consists of health posyandu (elderly, pregnant women, toddlers). Meanwhile, the PAUD program has not yet been opened because in the village of Sapala near the posyandu, there are already independent PAUDs with villages. The impacts 
obtained from health posyandu activities are health impacts and environmental impacts.

Table 5.26 Scope Creation and Stakeholder Identification of Sapala Village

\begin{tabular}{|c|c|c|c|}
\hline Scope / Stage & Stakeholders & Amount & Form of Role / Linkage \\
\hline \multicolumn{4}{|l|}{ Benefit recipients : } \\
\hline Mother's Posyandu & Pregnant mother & 16 people & $\begin{array}{l}\text { Pregnancy test } \\
\text { (ANC) } \\
\text { Giving additional tablets } \\
\text { blood } \\
\text { Pregnancy counseling } \\
\text { Giving birth control drugs }\end{array}$ \\
\hline Children's Posyandu & Toddler & 85 People & $\begin{array}{l}\text { Giving worm medicine } \\
\text { Giving vitamins } \\
\text { Feeding } \\
\text { Addition } \\
\text { Immunization } \\
\text { Weighing } \\
\text { Child nutrition education }\end{array}$ \\
\hline Elderly Posyandu & seniors & 70 people & $\begin{array}{l}\text { Drug administration } \\
\text { Medical examination } \\
\text { Health education }\end{array}$ \\
\hline \multicolumn{4}{|l|}{ Manager: } \\
\hline Planning and Principles & $\begin{array}{l}\text { Company } \\
\text { Village Apparatus }\end{array}$ & & $\begin{array}{l}\text { Building funding } \\
\text { Facility }\end{array}$ \\
\hline Implementation & $\begin{array}{l}\text { Medical personnel } \\
\text { Public health center } \\
\text { Posyandu cadres }\end{array}$ & & $\begin{array}{ll}\text { Activity } & \text { : Inspection } \\
\text { ANC, } & \text { counseling, } \\
\text { Immunization, } & \text { Giving } \\
\text { drug, } & \text { inspection } \\
\text { elderly health } & \\
\text { Activity } & \text { : counseling, } \\
\text { Giving } & \text { PMT, } \\
\text { weighing } & \end{array}$ \\
\hline
\end{tabular}

The integrated posyandu program in Tampakang village consists of two activities, namely health posyandu (elderly, toddlers, pregnant women) and PAUD. The impacts resulting from these 2 (two) activities are health, environmental and socio-cultural impacts 
Table 5.31 Scope Making and Identification of Stakeholders in Tampakang Village

\begin{tabular}{|c|c|c|c|}
\hline Scope / Stage & Stakeholders & Amount & Form of Role / Linkage \\
\hline \multicolumn{4}{|l|}{ Benefit recipients : } \\
\hline Mother's Posyandu & Pregnant mother & 8 people & $\begin{array}{l}\text { Pregnancy test } \\
\text { (ANC) } \\
\text { Giving additional tablets } \\
\text { blood } \\
\text { Pregnancy counseling } \\
\text { Giving birth control drugs }\end{array}$ \\
\hline Children's Posyandu & Toddler & 60 People & $\begin{array}{l}\text { Giving worm medicine } \\
\text { Giving vitamins } \\
\text { Feeding } \\
\text { Addition } \\
\text { Immunization } \\
\text { Weighing } \\
\text { Child nutrition education }\end{array}$ \\
\hline Elderly Posyandu & seniors & 60 People & $\begin{array}{l}\text { Drug administration } \\
\text { Medical examination } \\
\text { Health education }\end{array}$ \\
\hline PAUD & Toddler & 32 people & $\begin{array}{l}\text { early childhood } \\
\text { programs }\end{array}$ \\
\hline \multicolumn{4}{|l|}{ Manager: } \\
\hline Planning and Principles & \begin{tabular}{|ll} 
5. & Company \\
6. & Village Apparatus
\end{tabular} & & $\begin{array}{l}\text { Building funding } \\
\text { Facility }\end{array}$ \\
\hline Implementation & $\begin{array}{l}\text { 9. Medical personnel } \\
\text { Public health center } \\
\text { 10. Posyandu Cadre } \\
\text { 11. PAUD teacher }\end{array}$ & & $\begin{array}{lll}\text { Activity } & : & \begin{array}{l}\text { Inspection } \\
\text { ANC, }\end{array} \\
\text { Immunization, } & \text { Giving } \\
\text { drug, } & \text { inspection } \\
\text { elderly health } & \\
\text { Activity } & : \text { counseling, } \\
\text { Giving } & \text { PMT, } \\
\text { weighing } & \\
\text { Activity : learning } \\
\text { early childhood }\end{array}$ \\
\hline
\end{tabular}

\section{DISCUSSION}

\section{Economic variables}

The important impacts of the community empowerment program in Paminggir District, Hulu Sungai Utara Regency are:

\section{a. COOPERATIVE}

Positive impact :
1) The community can take advantage of the savings and loan program in the Cooperative which is used as additional business capital

2) The availability of basic necessities at the cooperative makes it easier for the community to meet their daily needs and save on transportation costs for purchasing groceries.

This publication is licensed under Creative Commons Attribution CC BY. 
3) The availability of photocopiers, stationery materials (office stationery) makes it easier for the community to meet the needs of supporting schools, village offices, and others so they don't waste a lot of money because they look outside the village.

4) Cooperatives benefit from business results.

Negative impact :

There are not yet available tools and supporting materials for livelihoods, especially tools and materials for fishermen, thus increasing the cost of finding equipment out of the village.

\section{b. SKILL IMPROVEMENT PROGRAM}

Positive impact:

The increase in skills provided in each village adds to the insight and ability of the community in entrepreneurship. However, each village still has different skills taught, such as:

1) Advanced Training in Sewing Clothes (Ds. Ambahai)

2) Training on sewing bags from ilung (DS. Tampakang)

3) Advanced hydroponic training (Ds. Ambahai)

4) Hydroponic Advanced Planning (Ds. Ambahai)

5) Making fish crackers (Ds. Bararawa)

Negative impact :

1) The product of the community's business cannot be marketed properly, this is because the selling price of the product is too high for the surrounding community, the community has not found the right target market, the community does not know how to promote and market it well (does not increase income).

2) In the application of hydroponics, people feel a loss if they continue to grow hydroponic vegetables because the weather is hot and many plants die, the price is cheap while the capital is expensive.

\section{c. PAUD}

Positive impact :

1) Children get health education in PAUD schools such as washing hands with soap, eating what is good to eat, throwing garbage in its place, Early Childhood Education also requires children to be fully immunized as a condition for entering PAUD, thereby reducing the level of pain in children, as well as reducing medical costs. in children.

2) With the existence of PAUD, the community finds it difficult in terms of financing, because from some villages PAUD costs are free, some are paid but the highest is only Rp. 10,000, - per month. With the low cost, parents can use the money for other purposes.

\section{d. Toddler Posyandu, PREGNANT MOTHERS, ELDERLY}

Positive impact :
1) People feel that the cost of examinations, treatment and other services is cheap, so they don't spend a lot of money to recover from an illness.

2) Communities feel that they have easy access to posyandu for health checks so they do not spend a lot of money on transportation to reach posyandu services outside their village.

\section{e. MAULID HABSYI}

Positive impact :

Increase the value of income for the habsyi group because they can save the money given by the invitees which will be used for tool renewal.

\section{Health variable}

a) In general, the number of people using posyandu indicates the reason for using health facilities at the posyandu is because of easy access and economy. These two factors are the main reasons why people use posyandu.

b) Apart from these positive impacts, several problems were also found regarding the existence of unstable cadres. The unstable existence of cadres is caused by the voluntary participation of cadres so that it does not guarantee that cadres will continue to carry out their functions properly. Unstable economic conditions have also caused many active cadres to become inactive and even drop out. The decline in the performance of posyandu cadres was partly due to economic disturbances, cadre saturation due to routine activities and the lack of attention from the local government in supporting the implementation of activities at posyandu, for example the lack of facilities and infrastructure supporting posyandu activities. In addition, the lack of knowledge of posyandu cadres is due to the lack of information obtained about the development of posyandu,

\section{Socio-cultural variables a. PAUD School (Early Childhood Education)}

Positive:

Toddlers have the means to socialize with their peers. Toddlers can recognize letters and numbers early and stimulate their growth and development well. Toddlers and parents know about how to live healthy (how to wash hands with soap, eat nutritious food and others).

\section{b. Posyandu Toddlers, Pregnant Women, Elderly} Positive:

1) Mothers of toddlers, pregnant women and the elderly get a lot of knowledge about healthy living and disease prevention.

2) The community's healthy paradigm tends to be good with indications of choosing a health facility as a place for treatment (no longer going to traditional healers/smart people)

Negative: 
ISSN 2250-3153

There are still mothers of toddlers who are worried when their children have a fever after being immunized

\section{c. Maulid Habsyi Group}

Positive:

The community has a new means to socialize with a positive impact

\section{Environment variables}

a. Waste management

Waste Management has an impact:

Positive impact

1) Communities can benefit from a clean surrounding environment with collection activities from home to TPS

2) Communities can improve skills in separating wet and dry waste

3) Communities get skills in utilizing waste into organic compost

4) Communities feel the benefits in terms of health and economy. The benefits in terms of health are better because they are protected from infectious diseases such as diarrhea, typhoid, worms and other diseases due to vectors that live in waste with economic value with an increase in health status, namely the medical fee of Rp. 50,000, so if there are children, pregnant women are protected from disease. infectious disease for three types of disease, it reduces expenditure by Rp. 63.100.000/day for Ambahai sub-district. People get cleaner water due to less waste generation due to garbage collection activities

- $\quad$ Bararawa can reduce waste generation by 425.95 kg/day

- Ambahai 0

- Paminggir can reduce waste generation by 533.05 $\mathrm{kg} /$ day

- Paminggir Seberang can reduce waste generation by $379.05 \mathrm{~kg} /$ day

- Palbatu can reduce waste generation by 273.35 $\mathrm{kg} /$ day

- Tampakang can reduce waste generation by $441.35 \mathrm{~kg} /$ day

- Sapala can reduce waste generation by 519.4 $\mathrm{kg} / \mathrm{day}$

5) The community gets economic value from waste management with a fee of IDR 50,000/month

Negative impact :

It is with this management that if there is no good management, waste disposal is more likely to be piled up without being available to be used again for other purposes because of the lack of capacity and the absence of assistant staff in carrying out activities in the community.

\section{b. Clean water management}

Clean Water Management has an impact:

Positive impact :

This publication is licensed under Creative Commons Attribution CC BY. http://dx.doi.org/10.29322/IJSRP.11.08.2021.p11646
1) The community can benefit from the existence of clean water sources from river water, groundwater from drilled wells and dug wells, PDAM.

2) So the fulfillment of clean water becomes one of the indicators in improving health status.

3) The community can improve skills in clean water management with a fee system and form an organization that oversees the interests of the community in clean water management

4) Communities get skills in appropriate technology in carrying out water purification with simple methods and utilizing available natural resources in the village

5) The community feels the benefits in terms of better health because it avoids infectious diseases such as diarrhea, typhoid, helminthiasis and other diseases due to lack of clean water with economic value with an increase in health status, namely the cost of treatment is Rp. 50,000, so if there are children, pregnant women are protected from disease. communicable diseases for three types of disease then reduce expenditure by Rp. 63.100.000/day for Ambahai sub-district

People who get clean water also get economic value, namely:

1) Bararawa manages water with a piping system, namely by paying for every $1 \mathrm{~m} 3$ of 1500 , it will get a fund of Rp. 1,825,500 in every $\mathrm{m} 3$ of water that is distributed.

2) Ambahai gets 8 points with each barrel of $1200 / \mathrm{m} 3$ with a monthly payment of 10 thousand rupiah, he will get a fund of Rp. 9,280,000 in every $\mathrm{m} 3$ of water distributed

3) On the other side, there is a piping system provided by PDAM and PAMSIMAS starting in 2015.

4) Paminggir already has a piping system from PDAM in 2015 which is capturing 216 families from 245 households

5) If there is a piping system with a 1 RT system, you will get 1 barrel for 10 families sourced from dug wells with an admin payment of Rp. 1000 and a 1 month payment of Rp. 35,000, so you will get a fund of Rp. 53,424,000 in every $\mathrm{m} 3$ of water distributed.

6) Tampakang, who used to take from the rice fields, now no longer because there is already a dug well system through PAMSIMAS activities kegiatan

7) The stone pals for clean water have been obtained by the community from village funds.

Negative impact:

It is with this management that if there is no good management then:

1) People who cannot afford it will not get clean water, so it is necessary to provide information for people who cannot access clean water with a payment system by making appropriate technology for well water and river water so that it can be used in accordance with health standards. 
2) Based on WHO data (2000), it is estimated that there are more than 2 billion people per day affected by water shortages in more than 40 countries in the world. 1.1 billion do not get adequate water and 2.4 billion do not get proper sanitation. Meanwhile, in 2050 it is predicted that 1 in 4 people will be affected by the lack of clean water (Gardner-Outlaw and Engelman, 1997 in the UN, 2003).

3) Economic losses are about $2.4 \%$ of GDP or US\$13 per month per household (Asian Development Bank 1998 study).

4) There is still a lack of payment for clean water, which should be Rp. 111200/month from the maximum collected dues of Rp. 35,000. This is based on the general fact that production costs for all types of raw water are higher than tariffs. PDAM that uses springs as a raw water source, the average production cost is Rp. 787/m3, while the average tariff is Rp. $618 / \mathrm{m} 3$. PDAM that uses springs, deep wells and rivers at the same time, the average production cost is $\mathrm{Rp}$. $1,188 / \mathrm{m} 3$, and the average tariff is Rp. $1,112 / \mathrm{m} 3$. While PDAMs rely on rivers as their raw water source, the average production cost is Rp. $1,665 / \mathrm{m} 3$, and the average tariff is Rp. $1,175 / \mathrm{m} 3$.

\section{c. Feces and Wastewater Disposal}

Stool Management has an impact:

Positive impact :

1) The community can benefit from the existence of disposal in a place that has been required to be one indicator in improving health status.

2) The community can improve skills in making healthy latrines with an empowerment system with a fee system and form an organization that protects the interests of the community in managing feces and waste water.

3) Communities get skills in appropriate technology in treating waste water using a simple method, namely a simple filter processing method and utilizing available natural resources in the village.

4) The community feels the benefits in terms of better health because it is protected from infectious diseases such as diarrhea, typhoid, helminthiasis and other diseases with the presence of healthy latrines and wastewater treatment and has economic value with an increase in health status, namely medical costs of Rp. 50,000 , so if there are children, pregnant women who are spared from infectious diseases for three types of diseases then reduce expenses by Rp. 63.100.000/day for Ambahai sub-district

People who get clean water also get economic value, namely:

1) Pal Batu is a change in behavior patterns from people who initially dispose of river feces into healthy latrines by integrating with village administrators, through village funds.

2) Tampakang Healthy latrines have just started in 2019 and there are 4 healthy latrines.
3) Sapala to the village policy that healthy latrines are built every 1 RT as many as 2 pieces as public toilets, and for family toilets there are already $40 \%$ with selffinancing.

4) Paminggir there has been a change in the behavior of the community with the ownership of their own toilets by the community from 2015 which has reached 121 families from 245 households.

5) Paminggir Seberang there has been a change in behavior from 2011 which was provided free of charge by Adaro by providing tools and pipes with cement and labor prepared by the community.

6) Ambahai there are only 11 latrines available and there is a need for planning related to healthy latrine ownership.

7) Bararawa there are no activities in the construction of latrines and ownership of healthy latrines.

Negative impact :

In the form of this management, if there is no good management then: people who can't afford it will not get healthy latrines, it is necessary to provide information for the community about how to make simple latrines and how to process waste water into cheap, safe and affordable clean water at a high level. community economy and equitable distribution of healthy latrines with grant funds.

\section{CONCLUSION}

Based on these results, it can be concluded that:

1. Based on the economic variables in the community empowerment program in the form of cooperatives and skill improvement programs have a positive impact but there are also negative impacts, while the PAUD program, Posyandu for toddlers, pregnant women, the elderly and Maulid Habsyi have a good positive impact.

2. On the health variable, the positive impact is felt because of the posyandu for infants and toddlers, pregnant women and the elderly, but there are still some problems with the program.

3. Meanwhile, on socio-cultural variables, positive impacts can occur in PAUD school programs, Posyandu toddlers, elderly pregnant women, and the Maulid Habsyi Group, although the Posyandu program has a slight negative impact.

4. Environmental variables have a positive impact on waste management programs, clean water treatment, disposal of feces and wastewater, although these programs still have weaknesses that result in negative impacts.

5. Calculation of Social Return of Investment (SROI) for integrated posyandu program in Ambahai village $27.01: 1$, for Paminggir village $12.93: 1$, Paminggir Seberang village $17.73: 1$, Palbatu village $32.25: 1$, Tampakang village $33,60: 1$, Sapala village $39.44: 1$, Bararawa village $37.01: 1$. 


\section{REFERENCES}

Dessler, Garry, 2006, Manajemen Sumber Daya Manusia, Jakarta: Indeks.

Irwanto AK, Prabowo A. 2009. Kajian efektivitas program corporate social responsibility (CSR) Yayasan Unilever Indonesia. Jurnal Manajemen.

Kotler, philip dkk, 2000, Manejemen Pemasan Jasa di Indonesia Analis Perencanaan, Implementasi dan Pengendalian (edisi pertama) Jakarta: Salemba Empat. Nirmaya GC, Muflikhati I, Simanjuntak M. 2014. Pengaruh Program Corporate Social Responsibility (CSR) Terhadap Kesejahteraan Keluarga Di Sekitar Tambang. Jurnal Ilmu Keluarga \& Masyarakat. Jan 1;7(1):1929.

Laricha, Lithrone., Kosasih, Wilson., Permai, R., Tri., 2018. Pengukuran dan Analisis Indeks Kepuasan Masyarakat di Kantor Imigrasi Jakarta. Jurnal Ilmiah Teknik Industri (2018). Vo. 6 No.1, 35-42.

Pohan IS. 2007. Jaminan mutu layanan kesehatan: dasar-dasar pengertian dan penerapan. Jakarta: EGC

Sutowo IR. 2013. Analisis Indeks Kepuasan Masyarakat dan Manfaat Ekonomi Program Corporate Social Responsibility (CSR) Chevron Geothermal Salak, Ltd. Bidang Ekonomi di Kecamatan Pamijahan, Kabupaten Bogor.

Wijono D. 2008.Paradigma dan metodologi penelitian kesehatan. Surabaya: CV Duta Prima Airlangga.

Sutrisno, Edi., Mariyono, Joko., 2016. Pengaruh Kualitas Pepelayanan dan Kinerja Pegawai Terhadap Kepuasan Masyarakat (Keluarganya Warga Binaan Pemasyarakatan) Pada Lembaga Pemasyarakatan Kelas Iib Slawi 